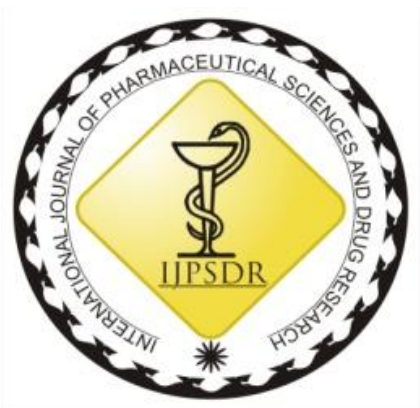

ISSN: 0975-248X

RESEARCH ARTICLE CODEN (USA): IJPSPP

(cc) EY-No-SA

\title{
Formulation and Evaluation of Polyherbal Face Scrubber for Oily Skin in Gel Form
}

\author{
J. Prathyusha*, N. S. Yamani, G. Santhosh, A. Aravind, B. Naresh \\ Bharat School of Pharmacy, Mangalpally, Ibrahimpatnam, Hyderabad, Telangana, India
}

Copyright (C) 2019 J. Prathyusha et al. This is an open access article distributed under the terms of the Creative Commons AttributionNonCommercial-ShareAlike 4.0 International License which allows others to remix, tweak, and build upon the work non-commercially, as long as the author is credited and the new creations are licensed under the identical terms.

\begin{abstract}
Cosmetics play a vital role for everyone to have a joyful and sanguine life. In present scenario herbal cosmeceuticals have more demand because they have no side effects. People having oily skin suffer from acne, whiteheads and blackheads quite often so scrubbing become more essential. In our present study we formulated 3 different formulations F1, F2, F3 in gel form for oily skin by using turmeric, aloe vera, cinnamon, potato starch, activated charcoal powder, honey, green tea, lemon juice, onion, walnut shell, coconut oil, beet root juice powder, sodium lauryl sulphate, water and evaluated by using various parameters such as physical appearance, viscosity, pH, Spreadability, irritability, washability, stability studies and got fruitful results with all the tests. The scrub F2 was found to show excellent effects on controlling oil secretion, and preventing formation of new pimples. The herbal formulation F2 was having characteristic odour, reddish brown in color having, light, non-irritant to the skin and quite elegant. The powder was smooth to touch and in gel form it spreads satisfactorily. Thus, the formulated scrub F2 can be utilized efficaciously without a side effect which exfoliates and makes glowing skin.
\end{abstract}

Keywords: Organogels, Hydrogels, Polymers, Antiseptic, Antimicrobial.

DOI: 10.25004/IJPSDR.2019.110404

Int. J. Pharm. Sci. Drug Res. 2019; 11(4): 126-128

*Corresponding author: Mrs. J. Prathyusha

Address: Bharat School of Pharmacy, Mangalpally, Ibrahimpatnam, Hyderabad, Telangana, India

Tel.: +91-9533426928

E-mail $\bowtie$ : prathyusha.rj@gmail.com

Relevant conflicts of interest/financial disclosures: The authors declare that the research was conducted in the absence of any commercial or financial relationships that could be construed as a potential conflict of interest.

Received: 24 June, 2019; Revised: 21 July, 2019; Accepted: 25 July, 2019; Published: 30 July, 2019

\section{INTRODUCTION}

Facial scrub is the cosmetic product which cleanses, exfoliates the skin of the face and gives healthy complexation. Generally, skins are of three types; dry skin, oily skin, and sensitive skin. The people with dry skin must use facial scrub which contains hydrating ingredients and moisturizer is must for them after using scrub. Gentle scrubs should be used for sensitive skin. For those who are having oily skin, it is essential to get a scrub that exfoliates deeply to prevent the pores from clogging and also to balance the skin's oil production. We can use a face scrub twice or thrice a week followed by lightweight face oil. Regardless of skin type, always we should select a scrub which is not hurtful but gentle to the skin. The harsh ones can do more harm than good to the skin. For oily skin, Gel based scrub is preferred. For dry skin, cream based scrub is useful. For sensitive skin, scrubs with super soft granules are having good results. An ideal scrub is accepted to possess the properties like it should be non 
toxic, possess small gritty particles, mild abrasive, non irritating, non sticky, able to remove dead skin cells.

Facial scrub in gel form is having many advantages than other formulations for topical application. Gels are the semi-solid dosage forms that are used for topical application. They are most predominant among all the semi-solid dosage forms. Gel is the network of mixture of gelling agent and a solvent. The drug molecules are embedded or entwined evenly in the solvent. Based on the nature of the solvent, gels are basically of two types, Hydrogels and Organogels. Gels are composed of two interpenetrating systems where the colloidal particles, also known as the gelator or gallant, are uniformly distributed throughout a dispersion medium or solvent forming a three dimensional matrix known as the gel. [1-2] The gels are prepared by adding a gelling agent (gelator) which could be natural, synthetic or semisynthetic polymer or low molecular weight small molecules, into an organic, inorganic or aqueous solvent or solvent systems. ${ }^{[3-6]}$ The polymer in gels acts as the backbone of the gel matrix. The polymeric meshwork gives gel its structural strength, increased adherence to the surface where applied and decreased permeation of the larger molecules hence making the retention possible. ${ }^{[7]}$ During the gel formation, swelling occurs as a result of solvent penetration causing the polymer network to stretch and hold its shape and entwine the drug particles in them. ${ }^{[7-8]}$ Viscosity plays an important role in the preparation of a gel. Gel present in its solution form requires a specific concentration of polymer to increase its viscosity. ${ }^{[8]}$

Our existing products in the market contain synthetic chemical ingredients of polymers like microplastics, gelling agents like carbopol, humectants like propylene glycol, coloring agent and preservatives like methyl paraben and propyl paraben that can cause irritation to the sensitive skin and may pollute the environment. Our present work aimed at formulating the scrub containing herbal gelling agent (potato starch), humectants (honey), coloring agent (beet root juice) so that it has no side effects and contains herbal products also as excipients.

\section{MATERIALS AND METHODS \\ Materials}

All the ingredients were powdered and sieved through sieve no. 120. Then they were packed in moisture resistant, well closed containers. The different ingredients with their key uses are enlisted in table 1.

\section{Preparation of extract}

The extract was prepared by cold maceration process. All the active ingredients (turmeric, cinnamon, aloe vera, activated charcoal, honey, green tea, lemon juice, onion, coconut oil) were ground and kept in water for 72 hours. This was dried and kept in desiccator for further process.

\section{Preparation of gel}

Sodium lauryl sulphate was weighed and dissolved in water and this solution is added to the potato starch which is used as a gelling agent. To this add the above prepared extract and stirred it for $5 \mathrm{~min}$. Walnut shell microbeads added to this mixture which gives grittiness to the gel.

\section{Table 1: List of ingredients used for formulation}

\begin{tabular}{|c|c|c|}
\hline $\begin{array}{l}\text { S. } \\
\text { No }\end{array}$ & $\begin{array}{l}\text { Name of the } \\
\text { ingredient }\end{array}$ & Uses \\
\hline 1. & Turmeric & $\begin{array}{l}\text { Used as an Antibacterial, antifungal and } \\
\text { brings glow to the skin. }\end{array}$ \\
\hline 2. & Aloe-vera & $\begin{array}{l}\text { Moisturizing agent and delivers } \\
\text { smoothing property to the skin. }\end{array}$ \\
\hline 3. & Cinnamon & $\begin{array}{l}\text { Anti-inflammatory property, Removes } \\
\text { acne, scars and wrinkles. }\end{array}$ \\
\hline 4. & Potato starch & $\begin{array}{l}\text { Natural scrubber, skin lightening agent, } \\
\text { gelling agent. }\end{array}$ \\
\hline 5. & $\begin{array}{l}\text { Activated } \\
\text { charcoal } \\
\text { powder }\end{array}$ & $\begin{array}{l}\text { Activated charcoal removes dirt, } \\
\text { chemicals, bacteria, poisons, and other } \\
\text { micro-particles from the surface of skin, } \\
\text { brings flawless complexion and clears } \\
\text { acne. }\end{array}$ \\
\hline 6. & Honey & $\begin{array}{l}\text { Used as humectants and as nutrient, used } \\
\text { as thickening agent. }\end{array}$ \\
\hline 7. & Green tea & $\begin{array}{l}\text { Polyphenols containing green tea helps in } \\
\text { anti ageing, skin looks younger and } \\
\text { attractive. }\end{array}$ \\
\hline 8. & Lemon & $\begin{array}{l}\text { The high content of Vitamin } C \text { in lemon } \\
\text { will help to lighten the skin tone and } \\
\text { remove dark spots which were caused by } \\
\text { skin tan. }\end{array}$ \\
\hline 9. & Onion & Acne, blackheads for blemished skin. \\
\hline 10. & Walnut shell & $\begin{array}{l}\text { Exfoliator that gently removes impurities } \\
\text { and dull cells leaving skin instantly } \\
\text { smooth and radiant }\end{array}$ \\
\hline 11. & Coconut oil & Nutrient, Skin tonic and emollient. \\
\hline 12. & $\begin{array}{l}\text { Beet root juice } \\
\text { powder }\end{array}$ & $\begin{array}{l}\text { It is used as a coloring agent. It also gives } \\
\text { healthy and glowing skin. }\end{array}$ \\
\hline 13. & $\begin{array}{l}\text { Sodium lauryl } \\
\text { sulphate }\end{array}$ & $\begin{array}{l}\text { Surfactant used as a cleaning and foaming } \\
\text { agent }\end{array}$ \\
\hline 14. & Water & Solvent \\
\hline
\end{tabular}

Table 2: Composition of developed formulation.

\begin{tabular}{lllll}
\hline S. & Ingredients & \multicolumn{3}{c}{ Quantity taken for 10 g gel } \\
\cline { 3 - 5 } No & & F1 & F2 & F3 \\
\hline 1. & Turmeric & $0.5 \mathrm{~g}$ & $0.5 \mathrm{~g}$ & $0.5 \mathrm{~g}$ \\
2. & Aloe vera & $0.7 \mathrm{ml}$ & $0.7 \mathrm{ml}$ & $0.6 \mathrm{ml}$ \\
3. & Cinnamon & $0.01 \mathrm{~g}$ & $0.01 \mathrm{~g}$ & $0.01 \mathrm{~g}$ \\
4. & Potato starch & $0.5 \mathrm{~g}$ & $0.75 \mathrm{~g}$ & $0.25 \mathrm{~g}$ \\
5. & Activated Charcoal & $0.2 \mathrm{~g}$ & $0.2 \mathrm{~g}$ & $0.3 \mathrm{~g}$ \\
6. & Honey & $3 \mathrm{ml}$ & $4 \mathrm{ml}$ & $3 \mathrm{ml}$ \\
7. & Green tea & $0.2 \mathrm{~g}$ & $0.1 \mathrm{~g}$ & $0.1 \mathrm{~g}$ \\
8. & Lemon & $0.7 \mathrm{ml}$ & $0.8 \mathrm{ml}$ & $0.7 \mathrm{ml}$ \\
9. & Onion & $0.01 \mathrm{ml}$ & $0.01 \mathrm{ml}$ & $0.01 \mathrm{ml}$ \\
10. & Walnut shell & $0.5 \mathrm{~g}$ & $0.5 \mathrm{~g}$ & $0.5 \mathrm{~g}$ \\
11. & Coconut oil & $0.2 \mathrm{ml}$ & $0.2 \mathrm{ml}$ & $0.2 \mathrm{ml}$ \\
12. & Beet root juice powder & $0.2 \mathrm{ml}$ & $0.2 \mathrm{ml}$ & $0.2 \mathrm{ml}$ \\
13. & Sodium lauryl sulphate & $0.01 \mathrm{~g}$ & $0.01 \mathrm{~g}$ & $0.01 \mathrm{~g}$ \\
14. & Water & q.s & q.s & q.s \\
\hline
\end{tabular}

\section{Evaluation}

Color: The color of the face wash gel was checked visually.

Odour: The formulation was evaluated for its odour by smelling it.

$\mathrm{pH}: 1 \%$ solution of our sample was measured by using a digital $\mathrm{pH}$ meter at constant temperature. [9]

Consistency: It was tested manually.

Spreadability: Two slides are taken and herbal sample was placed on one slide. Other slide was placed on the 
first slide. $100 \mathrm{~g}$ of weight was kept on the slides so that it spreads as a thin layer. Weight was been eliminated much high than the prisons. Next weight of $20 \mathrm{~g}$ was kept on the upper slide. It was performed for 3 times and average was calculated.

Spreadability was calculated by using the following formula,

$$
\mathrm{S}=\mathrm{M} \times \mathrm{L} / \mathrm{T}
$$

Where, S- Spreadability; M- Weight tied to the upper slide $(20 \mathrm{~g})$; Length of the glass $(6.5 \mathrm{~cm})$; Time in sec.

Viscosity: Brookfield viscometer was used to measure the viscosity of our sample. Viscosity of sample and water were taken in poise.

Washability: Formulations when applied on the skin can be easily removed by washing with water were tested manually.

Grittiness: The product was checked for the presence of any gritty particles by applying it on the skin

Foamability: Small amount of gel was taken in a beaker containing water. Initial volume was noted; beaker was shaken for 10 times and noted the final volume. Grittiness: The formulation was checked for the presence of any gritty particles by applying it on the skin.

Patch test: Patch testing is well established method for diagnosing the hypersensitivity as well as to determine the potential of a specific substance to cause the allergic action on patient skin. In patch test a small area of skin is exposed to those chemicals in dilute form whose specific effect on skin is to be studied. In patch test reaction of formulation on skin is observed in 2-3 days.

Stability studies [10]: the stability of the formulation was tested by filling the scrub in plastic containers and placing it in humidity chamber at $45^{\circ} \mathrm{C}$ and $75 \%$ relative humidity. The stability of the formulation was inspected for 3 months at interval of one month each.

Table 3: Evaluation parameters for polyherbal facial scrub

\begin{tabular}{|c|c|c|c|c|}
\hline \multirow{2}{*}{$\begin{array}{l}\text { S. } \\
\text { No }\end{array}$} & \multirow[t]{2}{*}{ Parameters } & \multicolumn{3}{|l|}{ Observation } \\
\hline & & F1 & F2 & F3 \\
\hline 1. & Colour & $\begin{array}{l}\text { Reddish } \\
\text { brown }\end{array}$ & $\begin{array}{l}\text { Reddish } \\
\text { brown }\end{array}$ & $\begin{array}{l}\text { Reddish } \\
\text { brown }\end{array}$ \\
\hline 2. & Odour & Characteristic & Characteristic & Characteristic \\
\hline 3. & $\mathrm{pH}$ & 6.0 & 5.8 & 6.2 \\
\hline 4. & Consistency & Semi-solid & Semi-solid & Semi-solid \\
\hline 5. & Spreadability & $4.8 \mathrm{~g}-\mathrm{cm} / \mathrm{sec}$ & $5.6 \mathrm{~g}-\mathrm{cm} / \mathrm{sec}$ & $4.1 \mathrm{~g}-\mathrm{cm} / \mathrm{sec}$ \\
\hline 6. & Viscosity & 1.4 poise & 1.7 poise & 1.2 poise \\
\hline 7. & Washabiity & Good & $\begin{array}{l}\text { Easily } \\
\text { washable }\end{array}$ & Good \\
\hline 8. & Grittiness & No & No & No \\
\hline $\begin{array}{l}9 . \\
10 .\end{array}$ & $\begin{array}{l}\text { Foamability } \\
\text { Patch test }\end{array}$ & $\begin{array}{l}150 \mathrm{ml} \\
\text { no allergic } \\
\text { action }\end{array}$ & $\begin{array}{l}150 \mathrm{ml} \\
\text { no allergic } \\
\text { action }\end{array}$ & $\begin{array}{l}150 \mathrm{ml} \\
\text { no allergic } \\
\text { action }\end{array}$ \\
\hline
\end{tabular}

\section{RESULTS AND DISCUSSION}

Formulation F1, F2, F3 was tested using various evaluation parameters. Spreadability, viscosity and $\mathrm{pH}$ of F2 formulation was found very good when compared to F1 and F2.

Stability studies: stability studies of F2 formulation gives good results during 3 months and the values are below.

\begin{tabular}{|c|c|c|c|c|}
\hline Parameter & Initial & $1^{\text {st }}$ month & $2^{\text {nd }}$ month & $3^{\text {rd }}$ month \\
\hline Colour & $\begin{array}{c}\text { Reddish } \\
\text { brown }\end{array}$ & $\begin{array}{l}\text { Reddish } \\
\text { brown }\end{array}$ & $\begin{array}{l}\text { Reddish } \\
\text { brown }\end{array}$ & $\begin{array}{c}\text { Reddish } \\
\text { brown }\end{array}$ \\
\hline Odour & $\begin{array}{c}\text { characteris } \\
\text { tic }\end{array}$ & $\begin{array}{c}\text { characteris } \\
\text { tic }\end{array}$ & $\begin{array}{c}\text { characteris } \\
\text { tic }\end{array}$ & $\begin{array}{c}\text { characteris } \\
\text { tic }\end{array}$ \\
\hline $\begin{array}{c}\text { Spreadabili } \\
\text { ty }\end{array}$ & $\begin{array}{c}5.6 \mathrm{~g}- \\
\mathrm{cm} / \mathrm{sec}\end{array}$ & $\begin{array}{c}5.5 \mathrm{~g}- \\
\mathrm{cm} / \mathrm{sec}\end{array}$ & $\begin{array}{c}5.4 \mathrm{~g}- \\
\mathrm{cm} / \mathrm{sec}\end{array}$ & $\begin{array}{c}5.4 \mathrm{~g}- \\
\mathrm{cm} / \mathrm{sec}\end{array}$ \\
\hline $\mathrm{pH}$ & 5.8 & 5.7 & 5.6 & 5.5 \\
\hline Viscosity & 1.7 poise & 1.6 poise & 1.58 poise & 1.56 poise \\
\hline
\end{tabular}

All the ingredients used in this poly herbal facial scrub are our food ingredients. So, the chances for its side effects are less. F2 is more effective than F1 and F3. We can use this herbal facial scrub for getting best results for oily skin. The efforts are on to reformulate the scrub in a gel form in order to achieve better spreadibility along imparting emollient and smoothing action.

\section{ACKNOWLEDGEMENT}

We express our honest gratitude to Dr. Marina D'Souza, Principal of Bharat School of Pharmacy for her constant support and completion of our work. We would also like to convey our sincere thanks to our honorable chairman Ch. Venugopal Reddy garu for providing the facilities to carry out our work.

\section{REFERENCES}

1. Kaur LP, Guleri TK. Topical Gel: A Recent Approach for Novel Drug delivery. Asian Journal of Biomedical and Pharmaceutical Sciences. 2013; 3(17):1-5

2. Buerkle LE, Rowan SJ. Supramolecular gels formed from multi-component low molecular weight species. Chem Soc Rev. 2012; 41:6089-6102.

3. Rathod HJ, Mehta DP. A Review on Pharmaceutical Gel. International Journal of Pharmaceutical Sciences. 2015; 1 (1):33-47.

4. Jain NK. Pharmaceutical Product Development: CBS Publishers \& Distributors, New Delhi, 2006.

5. Murdan S. Organogels in drug delivery. Expert Opin Drug Deliv. 2005; 2:489-505.

6. Vintiloiu A, Leroux JC. Organogels and their use in drug delivery. A review. J Control Release. 2008; 125:179-192.

7. Labarre D, Ponchel G, Vauthier C. Biomedical and Pharmaceutical Polymers: Pharmaceutical Press, London, UK, 2010.

8. Florence AT, Attwood D. FASTtrack: Physical Pharmacy: Pharmaceutical Press, London, UK, 2007.

9. Dureja H, Kaushik D, Gupata M, Kumar V, Lather V. Cosmeceuticals: An Emerging Concept. Indian Journal of Pharmacology. 2005; 37 (3): 155-159.

10. Itoh $Y$, Ninomiya $Y$, Tajima S, Ishibashi A. Photodynamic therapy of acne vulgaris with topical delta-aminolaevulinic acid and incoherent light in Japanese patients. Br J Dermatol. 2001; 144: 575-579. 